\title{
Coastal Risk Forecast System
}

\author{
André Sabino $^{1}$, Armanda Rodrigues ${ }^{1}$, Pedro Poseiro ${ }^{2}$, Maria Teresa Reis ${ }^{2}$, Conceição J. Fortes ${ }^{2}$ \\ and Rui Reis ${ }^{2}$ \\ ${ }^{1}$ Nova LINCS, Departamento de Informática, Faculdade de Ciências e Tecnologia, \\ Universidade Nova de Lisboa, Caparica, 2829-516, Portugal \\ ${ }^{2}$ Hydraulics and Environment Department (DHA), National Laboratory for Civil Engineering (LNEC), \\ Av. do Brasil, 101, Lisbon, 1700-066, Portugal \\ amgs@campus.fct.unl.pt, a.rodrigues@fct.unl.pt, \{pposeiro, treis, jfortes, rreis\}@lnec.pt
}

Keywords: Risk Management, Early Warning, Consequence and Risk Maps, Geographic Information Systems.

\begin{abstract}
Runnup and overtopping are the two main sea wave originated events that threat coastal structures. These events may cause destruction of property and the environment, and endanger people. To build early warning forecast systems, we must take into account the consequence and risk characterization of the events in the affected area, and understand how these two types of spatial information integrate with sensor data sources and the risk determination methodology. In this paper we present the description and relationship between consequence and risk maps, their role on the risk calculation, and how the HIDRALERTA project integrates both aspects into its risk methodology. We present a case study for Praia da Vitória port, in Azores Portugal.
\end{abstract}

\section{INTRODUCTION}

In coastal zones and ports, the evaluation of wave runup and overtopping of maritime structures is very important to assess the risk related with both the failure of those structures or the flooding of the protected regions. In Portugal, due to its coastline length, the concentration of population and economic activities close to the sea, its severe sea-wave climate, and the relevance of ports for the national economy, the study of wave run-up and overtopping is particularly important.

In fact, emergency situations caused by sea-waves hitting the coast are common, usually endangering the safety of people and goods, with serious consequences for the economy and society. Recent examples of such events in Portugal are:

Esmoriz. Flooding due to overtopping of the seawall in February 2011, with damages in the infrastructure and homes along the seafront;

Estoril. Frequent overtopping of the seawall, which affects its use and disrupts the nearby railway line;

Praia da Vitória Port, Azores. Strong overtopping of the breakwaters completely destroyed the structures after a December 2001 storm;

Marina do Lugar de Baixo, Madeira. Repeated events of massive overtopping of the breakwater in 2006, damaging the structure quite seriously and leading to the marina inoperability.

Therefore, it is deemed of paramount importance to implement an early warning system able to forecast the occurrence of emergency situations, enabling the adoption of measures to prevent live loss by the national or local authorities, and reduce economic and environmental damages.

This is the context of the HIDRALERTA project, whose goals are to design and implement the early warning system for the Portuguese coastal areas, mainly focused on the forecast of wave run-up and overtopping events. To further understand and predict run-up and overtopping events, the project also aims to propose and validate a methodology for long-term planning and forecast. The methodology is being instantiated with a case study, and is already using real data.

As a long-term planning tool, the system uses datasets of several years of sea-wave characteristics and/or pre-defined scenarios, and evaluates the seawave risks for the protected areas, allowing the construction of Geographic Information Systems (GIS) based risk maps. These maps aim to support the responsible entities' decision-making process regarding long-term management.

As a forecast and early warning tool, the system uses numerical forecasts of sea-wave characteristics 


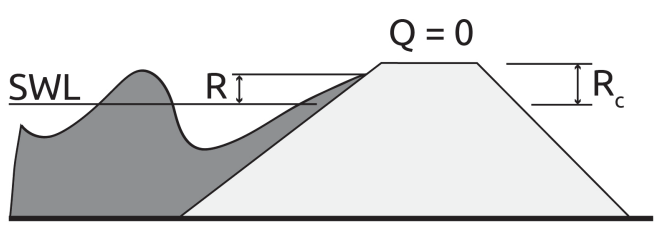

(a) Wave runup

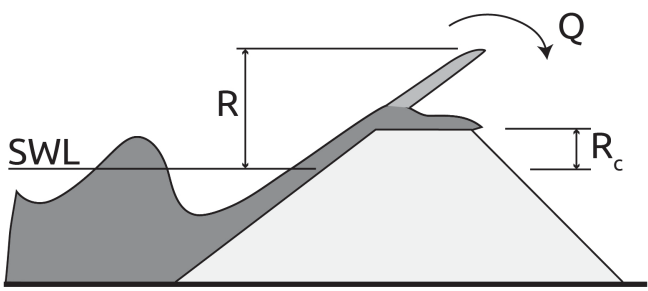

(b) Wave runup and overtopping

Figure 1: Representation of wave runup, $R$, and overtopping (mean discharge, $Q$ ) events on a structure with freeboard $R_{C}$ (still water level, $S W L$ ).

that enable the identification, in advance, of the occurrence of emergency situations, prompting the responsible entities to adopt measures to avoid loss of lives and minimize damage.

Furthermore, this methodology enables tools that contribute to the fulfillment of the directive 2007/60/EC of the European Parliament, and of the European Council of October 23, 2007, which has recommended the development of risk maps by 2013, and flood risk management plans, including the establishment of systems of forecasting and early warning, by 2015 .

The early warning system module is already running on a daily basis for Praia da Vitória Port, in Terceira Island, Azores, Portugal. Currently, it is being deployed on S. João da Caparica beach, in Costa da Caparica, Portugal.

Several aspects of the methodology followed by the HIDRALERTA have been presented in previous work (Sabino et al., 2014). This work presents the latest developments of the project regarding risk and consequence maps production, and its integration with the alert dissemination component of the system.

The remaining of this paper is organized as the following:seciton 2 presents the HIDRALERTA project background and related work; section 3 presents the risk assessment methodology, including the definition of the consequence table and map (section 3.1); section 4 describes the warning system; section 5 presents the case study area, where the system is currently running; section 6 draws some conclusions.

\section{BACKGROUND AND RELATED WORK}

Our goal is to build warning systems for two types of events on coastal areas: wave run-up; and wave overtopping. Wave run-up occurs when a wave climbs a beach or structure slope. Overtopping occurs when a volume of water passes over the crest of a structure due to wave action, which may be caused by waves running up the structure slope, exceeding the structure freeboard, and passing a continuous sheet of water over the crest. Overtopping may also happen when a wave hits a vertical structure, sending a vertical plume of water over the crest, or when a wave breaks on the seaward face of the structure and produces splash. The diagrams in figure 1 show the conditions for run-up (figure 1(a)), and for run-up and overtopping (figure 1(b)) events.

In countries like Portugal, with a long coastline, it is extremely relevant to study wave induced risks, especially wave overtopping, given the importance of the socioeconomic activities in port/coastal areas and the severity of the sea conditions. In this context, the HIDRALERTA project has been developing a set of integrated decision-support tools for port and coastal management, whose focus is to prevent and support the management of emergency situations, and the long-term planning of interventions in the target area.

The stakeholders involved in this type of system are structure owners, civil protection authorities, and all other users of the target areas. The warning that is delivered to each type of user differs in the amount of information that characterizes the event. The project is developing a set of warning icons that can be associated with risk levels, which inform the responsible entities about the specific consequences to their interest area.

The HIDRALERTA project in motivated by previous work, such as the GUIOMAR project (Neves et al., 2009), which developed a GIS integrated system used for numerical modeling of wave propagation in coastal and port engineering studies.

Unlike countries such as the United Kingdom and the Netherlands, Portugal does not yet have a national flood forecast and warning system. In fact, the country actually lacks local systems.

Previous work on a system focused on the forecast of tidal floods at the North East Region of England (Lane et al., 2008) also provides context to the HIDRALERTA project. 
The most widely used tools for predicting wave run-up and overtopping, and the corresponding flooding on beaches, coastal, and port structures are empirical and semi-empirical formulas based on physical model tests or field studies, such as the semi-empirical model of Hedges \& Reis (Hedges and Reis, 1998), as presented in (Raposeiro et al., 2009).

However, the direct application of all these formulae is limited to specific wave or water level conditions and simple structural or beach configurations. Physical models remain the most reliable method for determining runup and overtopping, being used for prototype studies, as well as to provide data for the development, calibration and validation of other prediction methods.

Due to the continuous increase in computer performance, numerical models have been developed further, and are becoming increasingly attractive (Reis et al., 2011). They are more flexible than empirical formulas and physical models, but their use in practical engineering applications still has limitations (Neves et al., 2008).

Given the complexity of these prediction models, machine learning methods are also suitable for the task. Several artificial neural networks have been developed lately, including by team members (Mase et al., 2007) and by the CLASH project team (Coeveld et al., 2005).

Previous work on Project Life-Saver has been also essential for this work. That project dealt with the evaluation of current emergency measures in the context of the Alqueva dam break (Sabino and Rodrigues, 2009; Sabino et al., 2008; Nóbrega et al., 2008). In this context, an emergency scenario simulator was developed and integrated in a decision support system, involving several tools to aid risk management activities for flood emergency scenarios. These results have now been taken a step further, with the aim of automatically providing these tools in different geographic areas and by abstracting the work developed with the creation of generic platform to aid the evaluation of different risk situations in an emergency management context.

\section{RISK EVALUATION}

Every target area of the system is divided into stretches. Each stretch represents an area in space where the risk will be constant. In our case study, the target area is a port in Azores, which is divided into several stretches, representing port structures and segments of the seawall. Our methodology will determine, for a particular event, the risk levels associated with each stretch.

The consequence and risk associated with emergency events are the two most relevant concepts of the HIDRALERTA project methodology.

Consequence refers to the effects emergency events may have on the area, which are relevant to the emergency response and preparedness. Specifically, these effect refer to threats to human lives, property and the environment. Understanding the potential consequences of an emergency event is key to enable risk assessment.

Risk relates the consequences of an event with the probability of it ever occurring, with the actual value being computed by the expression

$$
\text { risk = event probability } \times \text { consequences },
$$

which balances the study of past event (mainly extreme events) with the assessment of the characteristics of the study area.

Equation 1 computes values in a particular scale, meaningful to the emergency management stakeholders. In our case study, the risk value is a level on an ordinal scale, between 0 and 4 , with 0 indicating no risk, and 4 the maximum risk. Eventually, each risk level will be associated with a set of emergency response actions for each stretch.

To compute a value in the risk ordinal scale, we define values associated with several consequence levels, as presented in Table 1. With these consequence levels we are able to build consequence maps for events.

We are also able to build risk maps, representing the spatial distribution of risk levels, which are suitable for warning.

\subsection{Consequence Map}

Table 1 describes the consequences level associated with different emergency scenarios. The table was developed in close collaboration with the Praia da Vitória Port Authority, and considers the consequences of dangerous events, and the expected impact for human lives, the environment, port management, and property. The levels in this table reflect the importance of dangerous events for risk level assessment, representing different degrees of response requirements and prioritization. For example, it is important to distinguish between an event with high probability of occurrence but with low consequences from an event with a low probability of occurrence but with very high consequences, which is typically more critical to manage. Figure 2 presents an example of a consequence map for the Praia da Vitória Port. 
Table 1: Descriptions of the several consequence levels.

\begin{tabular}{|c|c|c|c|c|c|c|c|}
\hline \multirow[b]{3}{*}{ Description } & \multicolumn{7}{|c|}{ Consequences (Guidelines) } \\
\hline & \multirow[b]{2}{*}{ People } & \multirow[b]{2}{*}{ Environment } & \multirow[b]{2}{*}{ Port Management } & \multicolumn{3}{|c|}{ Property } & \multirow[b]{2}{*}{ Level } \\
\hline & & & & Buildings & Equipment & Maritime Structure & \\
\hline Insignificant & $\begin{array}{l}\text { Almost no } \\
\text { injuries (bruises } \\
\text { at most). }\end{array}$ & $\begin{array}{l}\text { Almost no } \\
\text { environmental impact. }\end{array}$ & $\begin{array}{l}\text { Small changes to port } \\
\text { activities. }\end{array}$ & $\begin{array}{l}\text { Almost no exterior } \\
\text { damage. }\end{array}$ & Almost no damage. & $\begin{array}{l}\text { Damage in the active } \\
\text { area of the structure } \\
\text { requiring no } \\
\text { intervention. }\end{array}$ & 1 \\
\hline Marginal & $\begin{array}{l}\text { Single slight } \\
\text { injury. }\end{array}$ & $\begin{array}{l}\text { Small cargo spills (e.g., } \\
\text { oil). }\end{array}$ & $\begin{array}{l}\text { Some changes to port } \\
\text { activities; bad local } \\
\text { publicity for the port. }\end{array}$ & $\begin{array}{l}\text { Minor exterior and } \\
\text { interior damage. }\end{array}$ & $\begin{array}{l}\text { Minor damage } \\
\text { requiring no stopping; } \\
\text { almost immediate } \\
\text { problem resolution. }\end{array}$ & $\begin{array}{l}\text { Occurrence of block } \\
\text { movements and falls } \\
\text { without filter exposure; } \\
\text { immediate intervention } \\
\text { not required. }\end{array}$ & 2 \\
\hline Relevant & $\begin{array}{l}\text { Multiple slight } \\
\text { injuries or single } \\
\text { major injury. }\end{array}$ & $\begin{array}{l}\text { Some areas are } \\
\text { restricted due to } \\
\text { pollution caused by } \\
\text { cargo spills. }\end{array}$ & $\begin{array}{l}\text { Restrictions on loading } \\
\text { and unloading; possible } \\
\text { partial shutdown; bad } \\
\text { widespread publicity. }\end{array}$ & $\begin{array}{l}\text { Moderate interior } \\
\text { damage. }\end{array}$ & $\begin{array}{l}\text { Damage requiring } \\
\text { temporary equipment } \\
\text { downtime for repair. }\end{array}$ & $\begin{array}{l}\text { Occurrence of block } \\
\text { movement and falls } \\
\text { without filter exposure; } \\
\text { superstructure affected } \\
\text { but with no significant } \\
\text { movements. }\end{array}$ & 5 \\
\hline Serious & $\begin{array}{l}\text { Multiple major } \\
\text { injuries or single } \\
\text { fatality. }\end{array}$ & $\begin{array}{l}\text { Pollution episodes in } \\
\text { and out of port zone } \\
\text { with potential } \\
\text { irrecoverable losses to } \\
\text { the environment. }\end{array}$ & $\begin{array}{l}\text { Loading and unloading } \\
\text { are impossible for } \\
\text { several days; bad } \\
\text { national publicity. }\end{array}$ & $\begin{array}{l}\text { Major interior damage; } \\
\text { building structure } \\
\text { affected. }\end{array}$ & $\begin{array}{l}\text { Major damage; } \\
\text { prolonged equipment } \\
\text { downtime. }\end{array}$ & $\begin{array}{l}\text { Filter layer affected; } \\
\text { substantial movements } \\
\text { of the superstructure. }\end{array}$ & 10 \\
\hline Catastrophic & $\begin{array}{l}\text { Multiple } \\
\text { fatalities. }\end{array}$ & $\begin{array}{l}\text { Widespread cargo } \\
\text { spills; serious } \\
\text { contamination; } \\
\text { irrecoverable losses to } \\
\text { the environment; } \\
\text { international aid } \\
\text { needed. }\end{array}$ & $\begin{array}{l}\text { Very serious } \\
\text { constraints to loading } \\
\text { and unloading over a } \\
\text { long period; very } \\
\text { serious and long term } \\
\text { loss of trade; bad } \\
\text { international publicity. }\end{array}$ & $\begin{array}{l}\text { Very serious interior } \\
\text { damage; building } \\
\text { structure seriously } \\
\text { damaged; imminent } \\
\text { danger of collapse. }\end{array}$ & $\begin{array}{l}\text { Equipment loss (no } \\
\text { recovery possibility). }\end{array}$ & $\begin{array}{l}\text { Collapse of the } \\
\text { structure. }\end{array}$ & 25 \\
\hline
\end{tabular}

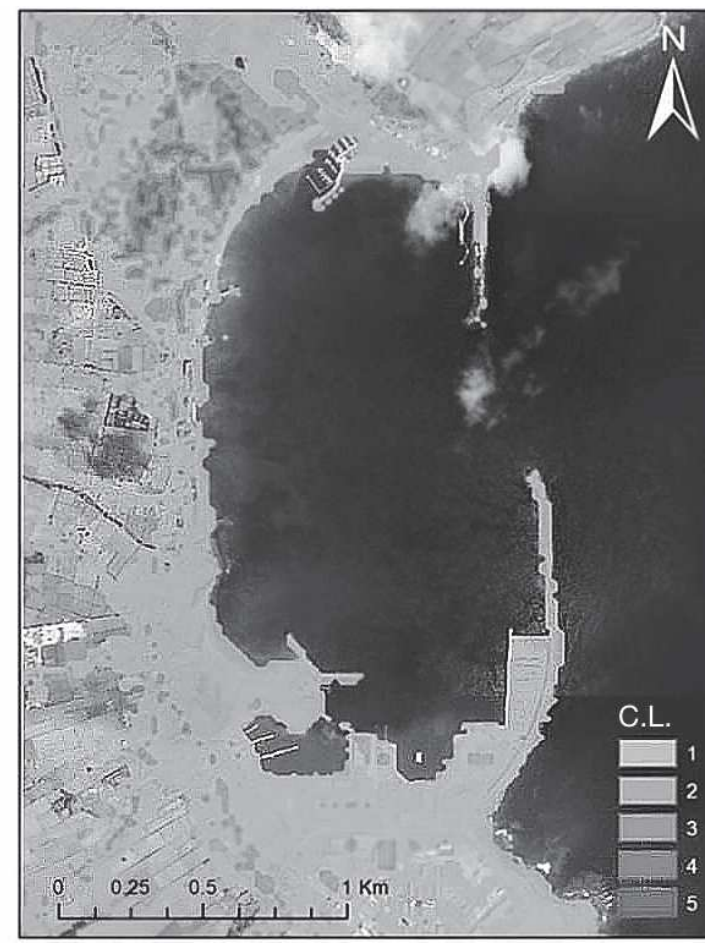

Figure 2: Praia da Vitória port consequence map, enabled by the AHP methodology. Consequence levels (C.L.) are represented by a color scale.

The consequences of run-up, overtopping, and flooding have been estimated using a methodology for a simple qualitative evaluation of the consequence level associated with hazardous events in the target area (Raposeiro et al., 2009). However, in that methodology there is no prioritization or allocation of weights to the different environmental, economic, and social aspects relevant to the target area, specifically for the occurrence of hazardous events that exceed pre-set thresholds. To complement the qualitative method for the determination of consequence levels, Poseiro, et al. (Poseiro et al., 2013), applied a methodology based on a multi-criteria analysis, which enables spatial analysis, classification, and assignment of weights to each aspect that characterizes the target area (Craveiro et al., 2012). This methodology for the establishment of the consequences map consists on the construction of a spatial index of human pressure on the port and coastal area through the application of the Analytic Hierarchy Process (AHP).

Recent developments include the application of AHP method in the port and bay of Praia da Vitória, Azores, and the application of Coastal Vulnerability Index and Hazard Assessment to obtain the Coastal Risk in sandy beaches with and without coastal defence structures in Costa da Caparica, near Lisbon, by using a geo-referenced database and the multi-criteria analysis.

\subsection{Risk Map}

The following five-step methodology relies on the concept of risk level to enable a qualitative assessment of wave overtopping risk: 


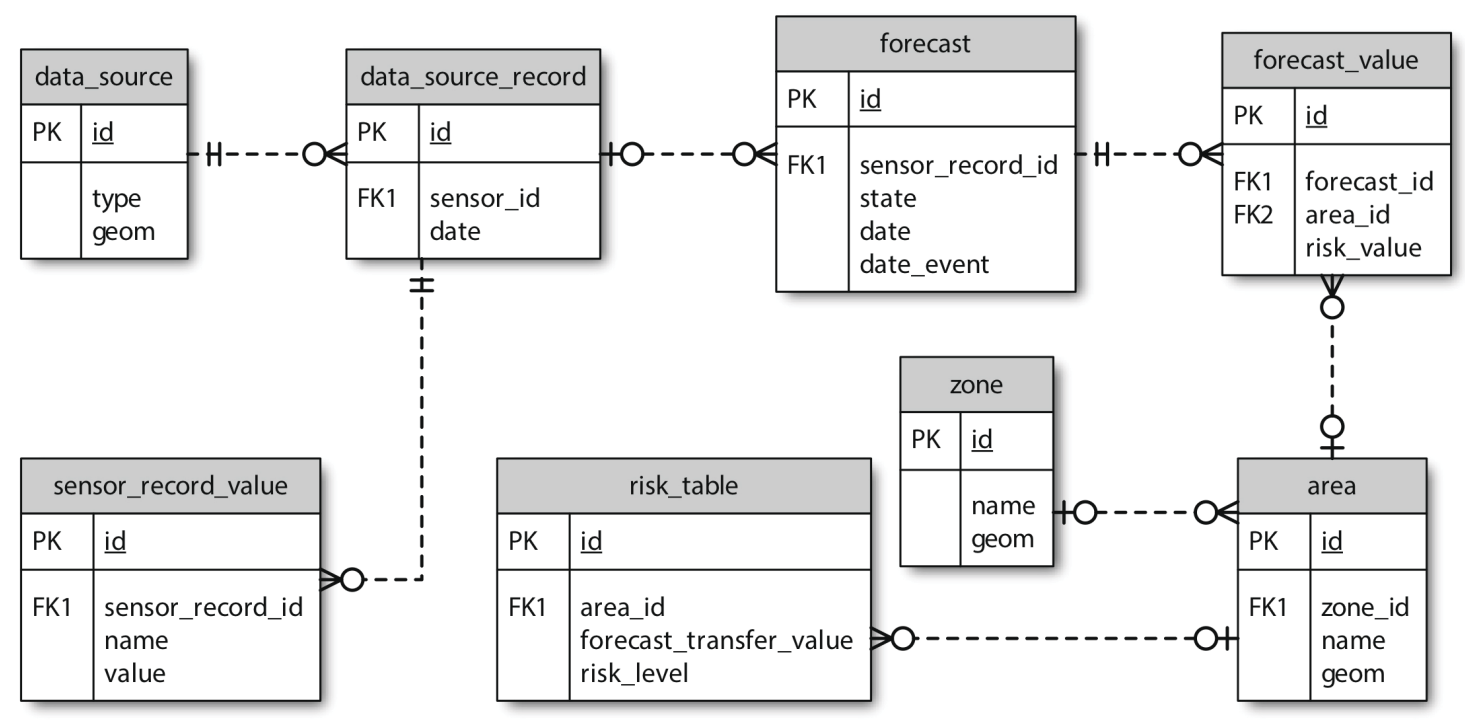

Figure 3: Data model of the risk database. It manages data from data sources and forecast components.

1. Defining acceptable thresholds for the overtopping values, guided by Pullen, et al. (Pullen et al., 2007a), and according to structures characteristics and utilization;

2. Defining, with table 1 , the probability level for the different thresholds;

3. Selecting the consequences level for each threshold in table 1;

4. Computing the risk level associated with the different preset thresholds;

5. Building risk level maps and analyzing risk levels acceptability.

With the evaluation of the mean overtopping discharges, the next step is the threshold definition of the overtopping discharge for each segment, according to the nature of the activities carried out in the area sheltered by it, and the overtopping impact on the safety of the structure itself, people, and infrastructure.

The set of thresholds is defined by the limits of the mean overtopping discharge per linear meter of the structure, as described by Pullen, et al. (Pullen et al., $2007 \mathrm{~b}$ ). We count the number of times those thresholds are exceeded in the relevant structures, estimate the associated probability of exceeding such thresholds, and determine the probability level, based on table 1. For each structure, the consequences level associated to the occurrence of mean overtopping discharges that exceed the same thresholds is established using table 1. Finally, the risk level is obtained by the product between probability levels and consequences levels.

\section{WARNING SYSTEM}

The warning system integrates the information generated by all the other components of the project. It is designed to assess and disseminate warnings of seawave runnup and overtopping events. It also deals with the different data sources that may be available to a particular scenario.

Specifically, the component deals with the following tasks:

- Data acquisition from the data sources;

- Trigger the wave overtopping determination component;

- Store risk assessment results;

- Disseminate current warning conditions through the following channels: Website, Twitter account, and Email;

- Maintain the zone characterization, using a map with the overtopping consequence layer and threat areas;

- Visualization tools for time series geo-referenced data sources and forecast data.

The system is managed through a web interface. It manages two types of data: from the data sources and interpolations, and the warning data. The data model in section 4.1 presents the data organization for data sources and interpolation. The warning data follows a straightforward CRUD design approach. 


\subsection{Architecture}

As mentioned previously, there are several data sources available. However, the relevant parameters collected from those sources remain the same: the significant wave height, the spectral peak period and the angle of wave attack.

The general architecture of the warning system is shown in figure 4.

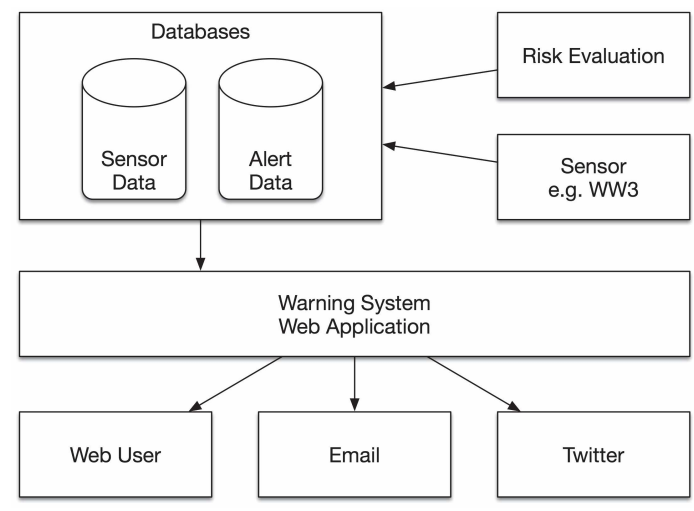

Figure 4: Warning system architecture.

Data collected from data sources are managed together with forecast data. Figure 3 illustrates the warning system data model that integrates information from data sources and the forecasting components.

The terms used in the data model are defined as the following:

Data Source. Any source that provides records with the three sea-wave parameters: significant wave height (meters), spectral peak period (seconds) and angle of wave attack (degrees).

Zone. The study area.

Area. A particular threat area inside the Zone that will be tested for potential overtopping events. Although there is an arbitrary number of areas inside a zone, these are subjected to what is possible to represent on the risk map.

Forecast. The value of potential overtopping discharges $(1 / \mathrm{s} / \mathrm{m})$, or wave runup for the set of threat areas, with one forecast value for each area.

Risk Area. The threshold table that relates a forecast value with a risk level, for each area. Different areas are subject to different thresholds.

Depending on the zone characteristics, the data source may be a single point location, like a single wave sensor buoy, or a collection of points, like a subset of the WAVEWATCH III grid. The forecast value also varies between a mean overtopping discharge value (NN_OVERTOPPING2) and wave runup information (which is exclusive to the empirical formulas approach).

The warning events' data is managed separately by the web application framework, referencing records on the risk database.

From the model in figure 3, each Forecast requires a specific Data Source Record. This record may refer to any type of sensor that outputs the parameters required by the feature model.

\section{CASE STUDY: PORTO DA PRAIA DA VITÓRIA AÇORES}

The port of Praia da Vitória, is located on the Praia da Vitória bay, at Terceira Island, the second largest of the Azores archipelago. Praia da Vitória bay is bordered to the north by Ponta da Má Merenda and to the south by Ponta do Baixio. Figure 5 provides an overview of the area.

In the early sixties, the north breakwater was built to protect the port facilities that support the Lajes airbase. It is a rubble-mound breakwater, $560 \mathrm{~m}$ long, with a north-south alignment, rooted in the Ponta do Espírito Santo. Later, in the eighties, the second breakwater (south breakwater) was built, rooted on the south side of the bay, near the Santa Catarina fort. The breakwater is approximately $1300 \mathrm{~m}$ long, with a straight alignment (north-south) that bends close to its shore connection. It protects the facilities (commercial sector and fishing port) of the Praia da Vitória port.

Taking advantage of the shelter provided by these breakwaters a marina was built in the late nineties by the Municipality of Praia da Vitória at the location of the former fishing harbour. The port basin is approximately $1 \mathrm{~km}$ by $2 \mathrm{~km}$.

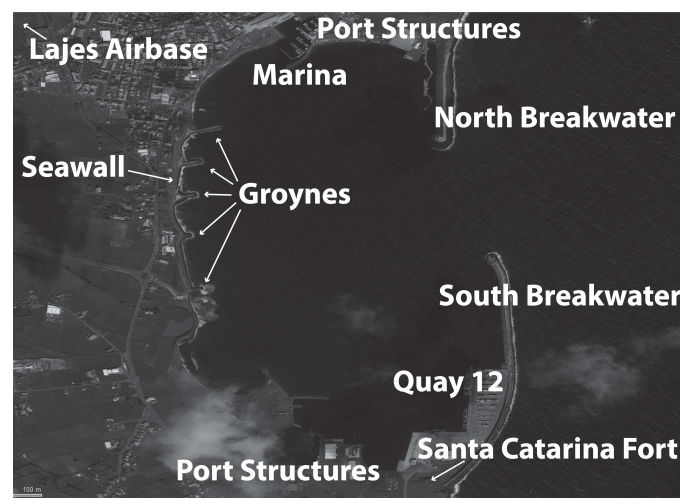

Figure 5: Main structures and areas of the Praia da Vitória port, Azores, Portugal. 
The bay shoreline has a $1 \mathrm{~km}$ long coastal defence. There is a field of five groynes in front of the port entrance, rooted to the coastal defense. Although these groynes do not have the same length, they have approximately the same alignment (WSW-ENE), and are referred to herein as groynes 1 to 5 , from south to north. At the root of groyne 3 there is a building, in which operates a bar. Between some of the groynes there are narrow beaches whose sand volume decreases as one moves south. The longest beach is located between groyne 5 and the marina jetty.

Presently, there are several sea-wave measuring devices that can characterize the sea wave regime within the port. In fact, within the scope of the CLIMAAT project (Esteves et al., 2009), a directional wave-buoy was deployed $4 \mathrm{~km}$ northeast from the port, in a region about $100 \mathrm{~m}$ deep, whose data were used to validate the methodology for wave propagation applied in this study.

The warning system is running permanently for Praia da Vitória. The sea-wave characterization module runs every day to predict 180 hours of wave characteristics at the port entrance and into the port, together with wind field and tide level predictions. Every 3 hours, the system creates a layout with significant wave height and angle of wave attack, as presented in figure 6.

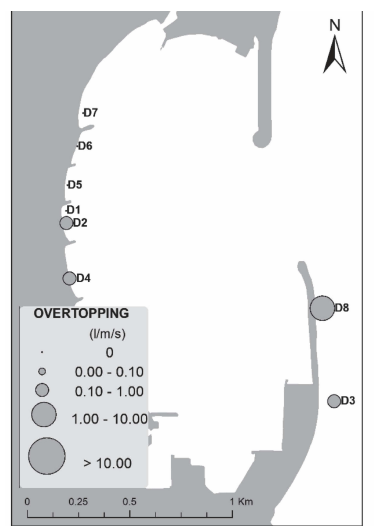

(a)

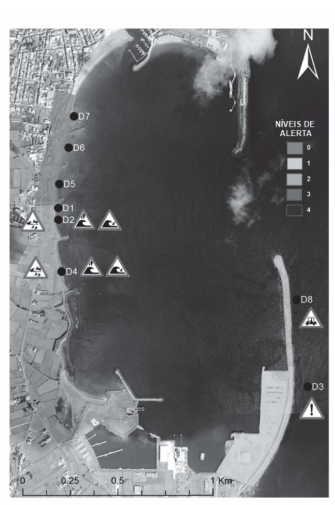

(b)
Figure 6: Examples of layouts created by the HIDRALERTA system for NN_OVERTOPPING2 results at October 16, 2010, 12:00. a) shows mean overtopping discharges at particular locations. b) shows the risk map presented to stakeholders, including warning information.

The risk assessment of Praia da Vitória permits the construction of risks maps in this area. In the qualitative risk evaluation, we considered a five-year period with sea-wave data from 2008 to 2012, as well as the effects of local wind and the astronomical tide level. The methodology was applied to eight structures along the port and bay of Praia da Vitória, from
D1 to D8 (see figure 7 a)). Example of a risk map is presented in figure $7 \mathrm{~b}$ ), which shows the regions where mitigation measures are to be implemented. The AHP methodology was employed to generate the consequences map (see figure 2).

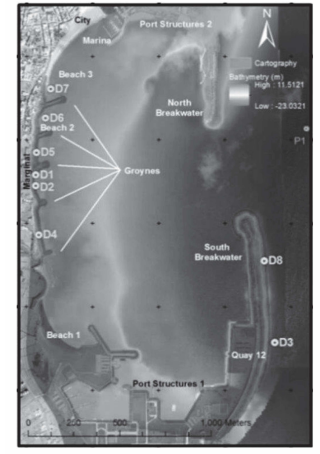

(a)

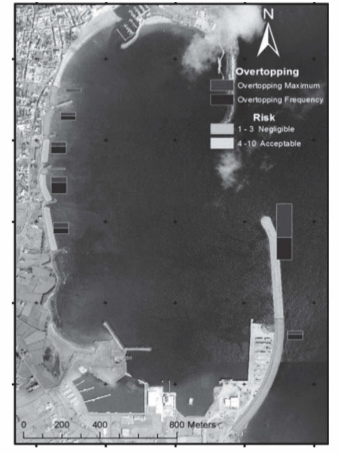

(b)
Figure 7: Examples of layouts created by the AHP methodology. a) shows the target area. b) shows the risk map.

Once the wave characteristics in the port are available, every 3 hours, the second module, which predicts the run-up/overtopping associated to those wave characteristics, is applied. For each set of wave/water level characteristics, NN_OVERTOPPING2 provides information on mean wave overtopping discharge for each of the studied cross-sections of the structures. If the mean overtopping discharge exceeds the pre-set threshold, a warning is issued. The WebGIS is presented at figure 8 .

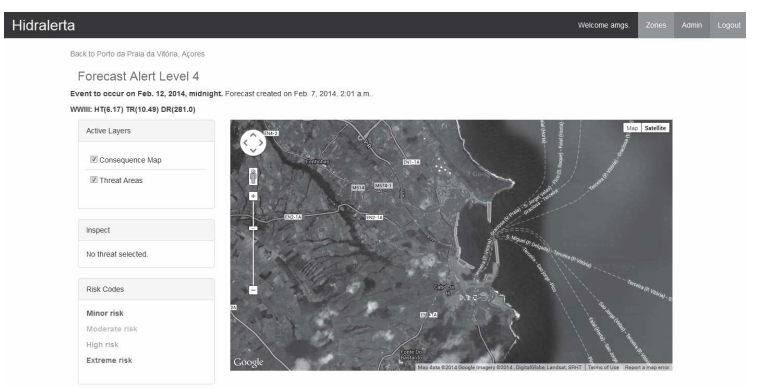

Figure 8: Example screen of the WebGIS component, with an example of a forecast alert. The system enables a color code representation of risk levels. Each stretch is represented by a polygon with the same color code of its risk level.

\section{CONCLUSIONS}

This paper presents the recent developments of the HIDRALERTA system, a novel system currently being implemented as an early warning application and 
also to assess the risk of flooding in coastal and port regions. The system, implemented in a WebGIS environment, follows the basic idea of using wave forecasts (up to 180 hours) to calculate the effects of waves on the coast, particularly in terms of wave overtopping and flooding. Once wave overtopping and flooding are evaluated, they are compared with predefined thresholds, to build warning maps and risk maps, and, if necessary, to issue warning messages.

Here we have described the application of the system to the Praia da Vitoria bay, in Terceira Island, Azores. It shows that HIDRALERTA system has the potential to become a useful tool for the management of coastal and port areas, due to its fast and efficient capacity to effectively issue warning and to evaluate risks. In the framework of the HIDRALERTA project, the system has also been applied to low-line areas, namely sandy beaches and dunes systems under pressure and higher vulnerable to climate changes impacts such as Costa da Caparica, either as a warning system or as a risk evaluation tool, but it can be easily extended to other locations. In fact, it has been applied to other Portuguese locations, such as the ports of Ponta Delgada (Azores) and Sines, and the Praia da Galé coastal area.

At this point, the project is developing:

- The replacement of the DREAMS linear wave model by the BOUSS-WMH nonlinear wave model;

- Carry out overtopping tests on physical models for other types of structures, being the data produced within these tests used in evaluating the performance of empirical, neuronal network or numerical tools;

- Improve the methodology for constructing maps of consequences;

- Create maps to enable illustration of the spatial distribution of successive volume thresholds, which will be complemented maps of consequences, and consequently maps of risk of overtopping/flooding;

- Set suitable levels (thresholds) to issue a warning.

\section{ACKNOWLEDGEMENTS}

This work is supported by Fundação para a Ciência e Tecnologia, Ministério da Educação e Ciência, Portugal, through grant PTDC/AAC-AMB/120702/2010. The authors are grateful for the information on Praia da Viória (port and bay) provided by Portos dos Açores, S.A., Anabela Simões and Eduardo Azevedo from Universidade dos Açores, and Conceição Rodrigues from Azorina - Sociedade de Gestão e Conservação da Natureza, S.A.

\section{REFERENCES}

Coeveld, E. M., Van Gent, M. R. A., and Pozueta, B. (2005). Neural network manual for NN_Overtopping program. Technical report, TU Delft.

Craveiro, J., Antunes, O., Freire, P., Oliveira, F., Almeida, I., and Sancho, F. (2012). Comunidades urbanas na orla costeira: a metodologia multicritério AHP (Analytic Hierarchy Process) para a construção de um índice de vulnerabilidade social face à ação marítima. In Atas do 2 Cong. Ibero Americano de Responsabilidade Social.

Esteves, R., Valente, A., Costa, M., Reis, F., and Azevedo, E. (2009). Dados Direccionais de Agitação Marítima nos Açores (Projecto CLIMAAT-Clima e Meteorologia dos Arquipelagos Atlânticos). In 6as Jornadas Portuguesas de Engenharia Costeira e Portuária.

Hedges, T. S. and Reis, M. T. (1998). Random wave overtopping of simple seawalls: A new regression model. Water, Maritime \& Energy Journal, 130(1):1-10.

Lane, A., Hu, K., Hedges, T., and Reis, M. (2008). New north east of England tidal flood forecasting system. In FLOODrisk 2008, Flood Risk Management: Research and Practice, pages 1377-1387, Oxford, UK.

Mase, H., Reis, M., Nagahashi, S., Saitoh, T., and Hedges, T. (2007). Effects of zero overtopping data in artificial neural network predictions. In Proceedings of the Coastal Structures'07, pages 2-4, Venice, Italy.

Neves, D. D. R., Zózimo, A. C. A., Fortes, C. a. J. C., and Pinheiro, L. (2009). GUIOMAR: Geo(graphical) User Interface for cOastal and MARine Modeling. Wave regime at Sines. Journal of Coastal Research, SI(56):1209-1213.

Neves, M. G., Reis, M. T., Losada, I., and Hu, K. (2008). Wave overtopping of Póvoa de Varzim breakwater: Physical and numerical simulations. Journal of Waterway, Port, Coastal and Ocean Engineering, 134(4):226-236.

Nóbrega, R., Sabino, A., Rodrigues, A., and Correia, N. (2008). Flood Emergency Interaction and Visualization System. In Proceedings of the 10th International Conference on Visual Information Systems.

Poseiro, P., Fortes, C., Reis, M., Simoes, A., Rodrigues, A., and Azevedo, E. (2013). A methodology for Overtopping Risk Assessment in Port Areas: Application to the Port of Praia da Vitória (Azores, Portugal). In 6th SCACR International Short Course / Conference on Applied Coastal Research.

Pullen, T., Allsop, N., Bruce, T., Kortenhaus, A., Schüttrumpf, H., and van der Meer, J. (2007a). Wave Overtopping of Sea Defences and Related StructuresAssessment Manual. Technical report.

Pullen, T., Allsop, N. W. H., Bruce, T., Kortenhaus, A., Schüttrumpf, H., and van der Meer, J. W. (2007b). Eu- 
rOtop Wave Overtopping of Sea Defences and Related Structures: Assessment Manual. Technical report.

Raposeiro, P. D., Reis, M. M. T., Fortes, C. a. J. C., and Ferreira, J. C. (2009). Methodology for estimating run-up and flooding at the costal zone using the GUIOMAR system: application to Vale do Lobo beach. In Proceedings of the COASTGIS'09, volume 2.

Reis, M., Neves, M., Lopes, M., Hu, K., and Silva, L. (2011). Rehabilitation of Sines West Breakwater: wave overtopping study. Proceedings of the ICE Maritime Engineering, 164(MA1):15-32.

Sabino, A., Nóbrega, R., Rodrigues, A., and Correia, N. (2008). Life-Saver: Flood Emergency Simulator. In Proceedings of the 5th International ISCRAM Conference, number May.

Sabino, A. and Rodrigues, A. (2009). A visual language for spatially aware agent-based modeling in crisis scenarios. In Proceedings of the 12th AGILE International Conference on Gepgraphic Information Science.

Sabino, A., Rodrigues, A., Araújo, J. a., Poseiro, P., Reis, M. T., and Fortes, C. a. J. (2014). Wave Overtopping Analysis and Early Warning Forecast System. In Murgante, B., Misra, S., Rocha, A. M. A. C., Torre, C., Rocha, J. G., Falcão, M. I., Taniar, D., Apduhan, B. O., and Gervasi, O., editors, Proceedings of the 14th International Conference on Computational Science and Its Applications, Guimarães, Portugal. 